\title{
The Patient with Multiple Endocrine Neoplasia Type 2B Treated with Citric Acid already Survived 8 Years Longer than Medically Expected
}

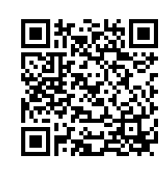

\author{
Alberto Halabe Bucay* \\ Director en Fundación, México. \\ Submission: December 19, 2016; Published:January 19, 2017 \\ *Corresponding author: Alberto Halabe Bucay, Director en Fundación, Prado Norte 460, Lomas deChapultepec, México, \\ Telephone/Fax: 5255-5029-5900; Email: doctorhalabe@hotmail.com
}

Abstract

This article describes the case of a male patient diagnosed with mutiple endocrine neoplasia type 2B who was treated with citric acid when he was 10 years old, the limit for survival for this disease, and he has survived in excellent conditions for 8 years.

Keywords: Cancer; Treatment; Citric acid; Multiple endocrine neoplasia

\section{Text}

In March 2009 was published in the journal Medical Hypotheses, from Elsevier, the case of a 10 years old male patient with a diagnosis of invasive multiple endocrine neoplasia 2B with elevated calcitonin regarding to an unresectable medullary thyroid cancer, which decreased more than 50\% with a treatment based on citric acid that the patient received orally since November, 2008 [1]; the patient began his treatment with citric acid, 3-5grams per day for the first year of treatment, after then it has taken orally intermittently by the patient and received many medical treatments; now, eight years later, the patient is alive, with excellent conditions; cervical node biopsies and thoracic biopsies were taken last November 1st, 2016 which were negative, and there is not clinical or radiological data of invasiveness at neck, chest, gastric or adrenal level; according to the literature, the survival of patients with multiple endocrine neoplasia $2 \mathrm{~B}$ with unresecable medullary thyroid tumor is up to 10years [2,3] regardless to the treatments received. This unexpected survival of 8 years longer than the medically expected can only be ascribed to the treatment with citric acid received by the patient.

I have already reported 13 cases of patients with cancer who have improved impressively only with the citric acid treatment that they have received, considering that they are literally cured, including this patient with medullary thyroid cancer [1], patients with peritoneal mesothelioma [4] myeloid leukemia
[5], Hürthle thyroid tumor [6], endocrine hepatic tumor [7], esophageal cancer [8], multiple myeloma [9], glioblastoma multiforme [10], pancreatic cancer [11] Non Hodgkin lymphoma [12] bladder cancer [13], breast cancer [14] and a patient with multiple myeloma remitted only in 10 days with the treatment of citric acid that she received [15]; also, the fact that citric acid [citrate] is effective as a cancer treatment is demonstrated in laboratory animals [16]; but this case reported in this article is very relevant, the survival rate of an endocrine neoplasia type 2B was overcome more than 8 years only with the treatment of citric acid that the patient received.

\section{Discussion}

This work is completely ethical, citric acid is a food, and is also effective as a treatment for Diabetes Mellitus, multiple sclerosis and other metabolic diseases [17].

\section{Conclusion}

All this undisputed evidence is enough to recognize that citric acid is effective as a cancer treatment.

\section{References}

1. Halabe Bucay A (2009) Hypothesis proved citric acid (citrate) does improve cancer: A case of a patient suffering from medullary thyroid cancer. Med Hypotheses 73(2): 271.

2. Pasquali D, Di Matteo FM, Renzullo A, Accardo G, Esposito D, et al. (2012) Multiple endocrine neoplasia, the old and the new: a mini review. G Chir 33(11-12): 370-373. 
3. Gertner ME, Kebebew E (2004) Multiple endocrine neoplasia type 2.Curr Treat Options Oncol 5(4): 315-325.

4. Bucay AH (2011) Clinical report: A patient with primary peritoneal mesothelioma that has improved after taking citric acid orally. Clin Res Hepatol Gastroenterol 35(3): 241.

5. Halabe Bucay A (2013) Report of a patient with leukemia who improved after taking citric acid orally. Glob Adv Res J Med and Medical Sci (GARJMMS) 2: 280-281.

6. Halabe Bucay A (2014) Case Report: A patient with a thyroid tumor that was reduced more tan $50 \%$ after taking citric acid orally. Int J Curr Med Res 3(2): 028-029.

7. Halabe Bucay A (2014) A patient with endocrine hepatic tumor who improved after taking citric acid orally. Int J Innovat Applied Res 2(4): 16-17.

8. Halabe Bucay A (2014) Pathological report of a patient with cancer of the esophagus improved considerably after receiving citric acid orally. Glob Adv Res J Med and Medical Sci (GARJMMS) 3: 159.

9. Halabe Bucay A (2014) Remission of multiple myeloma after receiving only citric acid orally. Glob Adv Res J Med and Medical Sci (GARJMMS) 3: $223-224$

10. Halabe Bucay A (2015) A patient with glioblastoma multiforme who improved after taking citric acid orally. Int Res J Basic Clin Stud 3(1): 35-37.
11. Halabe Bucay A (2015) Case Report: A Patient with pancreatic cancer who improved after the treatment with citric acid that she received. Indian J Appl Res 5(12): 392.

12. Halabe Bucay A (2015) A patient with Non Hodgkin Lymphoma that has survived more than 5 years after the treatment with citric acid that he received. Int J Res and Review 2(12): 769-770.

13. Halabe Bucay A (2016) Case Report: A patient with invasive bladder cancer who improved after the treatment of citric acid that he received. Int J Sci Res 5(5): 613

14. Halabe Bucay A (2016) A patient with breast cancer that dissapeared after the treatment with citric acid that she received. Int J Sci Res 5(6): 533.

15. Halabe Bucay A (2016) Citric acid (citrate) is the cure of cancer: the case of a patient with complete remission of multiple myeloma in 10 days after the treatment with citric acid that she received. Int J SCi Res 5(12): 683.

16. Peixoto R, Miranda Vilela A, de Souza Filho J, Brettas M, Oliveira R, et al (2015) Antitumor effect of free rhodium (II) citrate and rhodium (II) citrate-loaded maghemite nanoparticles in mice bearing breast cancer: a systemic toxicity assay. Tumor Biology 36(15): 3325-3336.

17. Halabe Bucay A (2016) Treatment of Diabetes Mellitus, multiple sclerosis and other "metabolic" diseases with citric acid. Int J Sci Res 5(9): 239-240.

Your next submission with Juniper Publishers will reach you the below assets

- Quality Editorial service

- Swift Peer Review

- Reprints availability

- E-prints Service

- Manuscript Podcast for convenient understanding

- Global attainment for your research

- Manuscript accessibility in different formats

( Pdf, E-pub, Full Text, Audio)

- Unceasing customer service

Track the below URL for one-step submission https://juniperpublishers.com/online-submission.php 